\title{
Ethics
}


In Business Now Series

Ethics Francis P. McHugh

Graphs and Charts Renée Huggett

Markets Renée Huggett

Retailing Peter Jones and Steve Baron 


\section{IN BUSINESS NOW}

\section{Ethics}

Francis P. McHugh

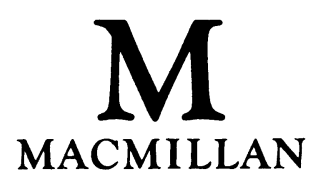


(C) Francis P. McHugh 1991

All rights reserved. No reproduction, copy or transmission of this publication may be made without written permission.

No paragraph of this publication may be reproduced, copied or transmitted save with written permission or in accordance with the provisions of the Copyright, Designs and Patents Act 1988 or under the terms of any licence permitting limited copying issued by the Copyright Licensing Agency,

33-4 Alfred Place, London WC1E 7DP.

Any person who does any unauthorised act in relation to this publication may be liable to criminal prosecution and civil claims for damages.

First edition 1991

Published by

MACMILLAN EDUCATION LTD

Houndmills, Basingstoke, Hampshire RG21 2XS

and London

Companies and representatives

throughout the world

Typeset and illustrated by TecSet Ltd, Wallington, Surrey

British Library Cataloguing in Publication Data

McHugh, Francis P.

Ethics.- (In business now)

1. Business enterprise. Ethical aspects

I. Title II. Series

174.4

ISBN 978-0-333-54446-4 ISBN 978-1-349-12149-6 (eBook)

DOI 10.1007/978-1-349-12149-6 


\section{Contents}

Acknowledgements

vii

1 What Business Ethics is about 1

2 A Fair Deal 8

3 Markets, Freedom and Responsibility 14

4 Does a Business have a Conscience? 20

5 Managers and Leadership 25

6 Ethics and the Consumer 32

7 Employers and Employees 39

8 Business as a Friend of the Universe 46

9 The World of Money 53

10 Fraud, Regulation and Business Ethics 63

11 Credit and Debt 70

12 Using Ethical Reasoning 77

$\begin{array}{ll}\text { Index } & 84\end{array}$ 


\section{Acknowledgements}

The author wishes to thank Ruth Maskery for invaluable help with research in the preparation of this book.

The support and encouragement of Von Hugel Institute, St Edmund's College, Cambridge, and Christian Social Ethics Research Unit are also gratefully acknowledged.

The author and publishers wish to thank the following who have kindly given permission for the use of copyright material.

The Advertising Standards Authority Ltd for material sourced to their publications;

Barclays Bank plc for their logo;

Birds Eye Wall's Ltd for advertising material;

Collins Publishers for a figure from Credit and Debt; Sorting it Out by Schluter and Lee, Marshall Pickering, 1989;

Corning Ltd, on behalf of Grey Ltd, for advertising material;

ECOTEC Research and Consulting Ltd for figure, 'Gross annual cost of pollution control by private sector industry 1988';

The Controller of Her Majesty's Stationery Office for Crown copyright material;

Hobsons Publishing plc for figure from Finding Out . . . About the City, 1989; Holden Meehan for table, 'Investment with Conscience';

Jubilee Centre Publications Ltd for data from the Jubilee Centre Debt Study Survey;

Charles Letts \& Co. Ltd for material from Business Studies by David Floyd, 1989;

Lloyds Bank for their logo;

McGraw-Hill Inc. for table from Business and Society by K. Davis and W. Frederick, 5th edition, 1984;

Midland Bank for their logo;

Monks Partnership Ltd for data on highly paid directors' salaries;

National Westminster Bank PLC for their logo;

Nationwide Anglia Building Society for their logo;

The Observer Ltd, for adapted tables 'Fatalities at work' and 'Construction: the most dangerous trade', The Observer, 6th May 1990; Times Newspapers Ltd for table on fraud, MORI/The Sunday Times, October, 1985.

Every effort has been made to trace all copyright holders, but if any have been inadvertently overlooked the publishers will be pleased to make the necessary arrangement at the first opportunity. 